\title{
Life Cycle Assessment of New Willow Cultivars Grown as Feedstock for Integrated Biorefineries
}

\author{
M. Krzyżaniak ${ }^{1}$ - M. J. Stolarski ${ }^{1}$ - S. Szczukowski ${ }^{1}$. J. Tworkowski ${ }^{1}$ \\ Published online: 10 October 2015 \\ (C) The Author(s) 2015. This article is published with open access at Springerlink.com
}

\begin{abstract}
The fossil fuel resources which power the chemical and energy industries are shrinking or becoming increasingly expensive. Moreover, their excavation and consumption have a negative impact on the environment, including global warming. For these reasons, new, cleaner, resources are being sought to replace them, such as lignocellulosic biomass. The aim of this study was to determine the environmental impact of the production of seven new cultivars of willow grown in a commercial plantation for use in an integrated biorefinery. The characteristics of the production and transport of 1 tonne of dry willow chips for the minimum (cultivar UWM 155), maximum (cultivar UWM 006) and average yield have shown that the cultivar with the lowest yield has the highest impact on the environment for all the selected categories of impact (CML 2 baseline 2000 method). For the average yield across all the cultivars, at a transportation distance of $25 \mathrm{~km}$, this study found a high environmental impact of mineral NPK fertilisation, biomass harvest and road transport. The stage of normalisation for the average yield showed that freshwater toxicity had the greatest impact on the environment of all the categories under study. The effect of the other categories was $22-76 \%$ lower for abiotic depletion and global warming, respectively. GHG emission amounted to $36 \mathrm{~kg} \mathrm{CO}_{2}$ eq. per $1 \mathrm{Mg}$ of dry willow chips transported for $25 \mathrm{~km}$, and it increased with an increase in the transport distance by 24 and $71 \%$ for 50 and $100 \mathrm{~km}$, respectively. The lowest GHG emission per $1 \mathrm{Mg}$ of dry chips was achieved for the production of
\end{abstract}

M. Krzyżaniak

michal.krzyzaniak@uwm.edu.pl

1 Faculty of Environmental Management and Agriculture, Department of Plant Breeding and Seed Production, University of Warmia and Mazury in Olsztyn, Plac Łódzki 3/420, 10-724 Olsztyn, Poland the high-yielding biomass cultivars UWM 006 and UWM 043. Their chips could be transported for longer distances, i.e. 50 and $100 \mathrm{~km}$, because their impact on global warming was much lower than the low-yielding cultivars UWM 155, Tur and UWM 035.

Keywords Willow biomass production $\cdot$ Life cycle assessment $\cdot$ New cultivars $\cdot$ Integrated biorefinery · Environmental impact

\section{Introduction}

Europe, as well as the whole world, is facing the problem of shrinking resources of fossil fuels. The peak of oil production will probably peak at 2030 [1]. The global oil production output in the period 2002-2013 increased by $11 \%$. New reserves of oil may be discovered all over the world, but it is usually more expensive to excavate than in the twentieth century due to an increasing share of production of oil from unconventional sources, such as tar sands. The peak of coal production will probably be achieved in 2025 as its resources are being used up more quickly than all other energy sources. Its consumption has increased by over $4 \%$ annually during the past decade $[2,3]$.

The production and consumption of fossil fuels entail serious environmental problems: emissions of GHG and, in consequence, aggravation of the greenhouse effect. The atmospheric concentrations of greenhouse gases: carbon dioxide $\left(\mathrm{CO}_{2}\right)$, methane $\left(\mathrm{CH}_{4}\right)$ and nitrous oxide $\left(\mathrm{N}_{2} \mathrm{O}\right)$ have all increased since 1750 due to human activity [4]. In 2011, the concentrations of those gases exceeded pre-industrial levels by about 40,150 and $20 \%$ respectively. These changes will have serious environmental effects $[4,5]$. 
For these reasons, new, cleaner resources are being sought to replace fossil fuels and fossil-based products. Efforts have been stepped up over the past 10 years to replace those materials with renewable and cleaner sources [6-8]. Examples include integrated multi-product biorefineries, e.g. the EuroBioRef concept. This assumes highly integrated and diversified production, including multiple feedstocks (including lignocellulosic biomass), multiple processes (chemical, biochemical, thermochemical) and multiple products (aviation fuels and chemicals). A flexible approach will widen biorefinery implementation to the full geographical range of Europe. Products obtained in biorefineries can successfully replace those obtained from fossil fuels, thereby decreasing the demand for them. On average, the EU member states depend $53.8 \%$ on fossil fuel supplies from third countries in 2011. The advantages of integrated biorefineries include the production of fuels in local plants located in EU Member States, which would make them less dependent on fossil fuels by obtaining feedstock from local biomass resources $[9,10]$.

However, the obtained bioproducts should meet the condition of being renewable and produced in a sustainable manner. According to Directive 2009/28/EC, the emission of GHG from biofuel production should be decreased by at least $35 \%$ and by over $60 \%$ after 1 January 2018. This directive also requires that biofuels should be produced in a manner which protects areas with high natural value, forests and marshes [11].

Lignocellulosic biomass has great potential for use in all conversion paths (thermochemical, chemical, biochemical) in an integrated biorefinery. It can also be obtained from forests, agricultural resources, as well as from waste. Lignocellulose can be used as feedstock in the production of over 30 intermediates for different products used in such branches as transport, production of textiles, food, packaging, cosmetics, construction materials and in leisure [7, 12]. Dedicated energy crops can be used as feedstock in biomass processing plants: herbaceous crops (Miscanthus spp.), short rotation woody coppices (willow and poplar species, black locust) and agricultural waste (straw, bean stalks, tree prunings) [13-17]. These species should be grown on agricultural land of lower quality, with low usability for edible crop production. This reduces the competition between edible and non-edible crops and has a smaller effect on direct and indirect land use change.

Short-rotation willow coppice can provide large amounts of biomass for biorefineries. Dry matter yield from commercial plantations ranges from 5 to $12 \mathrm{Mg} \mathrm{ha}^{-1}$ year $^{-1}$ and can reach $30 \mathrm{Mg} \mathrm{ha}^{-1}$ year $^{-1}$ on experimental field trials with good quality soils [18-22].

As mentioned, the idea behind the biorefinery concept is that energy should be produced in a sustainable manner. Therefore, obtaining biomass, which starts a logistical product chain, should have a small effect on the environment as possible. Life cycle assessment is a standardised method to examine or compare the effect of plants produced for industry or as an energy source (or any other product). According to the ISO 14040 standard, life cycle assessment is a compilation and evaluation of the inputs, outputs and the potential environmental impact of a product system throughout its life cycle [23]. LCA has its origin in studies conducted (by different companies, e.g. Coca-Cola) on energy effectiveness in the 1960s. However, it did not catch on until the 1990 s, when its widely accepted methodology was developed, including the ISO 14040-14044 standards [24]. The method was developed in the industrial sector, where the environmental impact was determined on the basis of streams of consumption of energy, raw materials and measurements of emissions from processes used in a specific technology. Currently, a number of studies are being conducted on the use of the method in many sectors of the economy. During the past 10 years, LCA has been used to determine the environmental impact of the agricultural sector in the production of meat, wool, dairy cow breeding, milk production, the production of fruit and vegetables in greenhouses and in field and growing energy crops, such as poplar, miscanthus and willow. The possibility of determining GHG emission levels is one of the major advantages of LCA in examination of the environmental impact of perennial energy crops [25-32]. Moreover, owing to LCA, it is possible to determine the entire environmental impact of the means of production, machines, equipment and energy during the process of willow production. Since lignocellulose can be an alternative feedstock for production of energy, biofuels and bioproducts, it is important to determine its environmental impact, to see if it meets the conditions set out for renewable biomass materials. For example, in the USA, LCA is a tool which is required by the US Energy and Investment and Security Act to determine the GHG reduction for advanced renewable fuels [33].

Therefore, the aim of this study was to determine the environmental impact of production of seven new cultivars of willow grown on a commercial plantation, set up on soil with low usability for the production of edible crops, for an integrated multi-product biorefinery. It was assumed in the experiment that the production technology would be analysed from the cradle to the gate of a biorefinery. Moreover, three different distances of biomass transport from the plantation to the biorefinery were analysed in the study.

\section{Materials and Methods}

In order to determine the environmental impact of the biomass production of seven willow cultivars for a biorefinery in a 3year harvest cycle, the study methodology was based on the following standards: PN-EN ISO 14040 "Environmental management-Life cycle assessment-Principles and framework" [23] and PN-EN ISO 14044 "Environmental management-Life cycle assessment-Requirements and guidelines" 
[34]. The data accumulated in the experiment were subjected to LCA using SimaPro 7.3.2 software (Pré Consultants bv).

\section{Description and Location of the Willow Plantation}

A 10.5-ha commercial willow plantation was established in April 2010 at the Educational Research Station in Łężany owned by the University of Warmia and Mazury in Olsztyn (UWM). It is located in north-eastern Poland near the village of Samławki $\left(53^{\circ} 59^{\prime} \mathrm{N}, 21^{\circ} 05^{\prime} \mathrm{E}\right)$. Three varieties of willow, protected by rights and registered at the Polish Research Centre for Cultivar Testing, as well as four new unregistered clones, were planted on the plantation. All of them were developed by the Department of Plant Breeding and Seed Production of the University of Warmia and Mazury in Olsztyn: the Salix viminalis varieties: Start, Tur and Turbo, and the clones: UWM 006 S. viminalis, UWM 043 S. viminalis, UWM 035 Salix pentandra and UWM 155 Salix dasyclados (further in this paper referred to as cultivars).

The planting density was 18,000 plants $\mathrm{ha}^{-1}$. The plant harvest was planned for 3-year cycles, which is optimal for willow cultivation on large plantations considering plant productivity and machine availability for a single stage biomass harvest technology.

The forecrop for the willow plants was triticale. Soil of low quality and usefulness for typical annual crops were selected for the willow plantation. The relatively poor soil site allowed the willow yield potential to be evaluated in areas of little use for food or feed crops. The study area is situated in a specific region, over a young glacial area with a varied terrain relief. The surface is undulating. Although the average willow field height differences amount to about $1.5 \mathrm{~m}$ and they reach up to $3.5 \mathrm{~m}$, the area is reasonably flat with no large hills or valleys. The conducted soil analyses showed that the willow plantation was located mainly on soil created from slightly loamy sand and light loamy sand.

Generally, the land in elevated areas causes the soil to be permanently too dry (in periods with no precipitation) due to rapid drainage, and the groundwater level is far below $150 \mathrm{~cm}$.

\section{LCA Methodology}

\section{Goal, Scope and Functional Unit}

The aim of the study was to conduct a life cycle assessment of seven willow cultivars in a 3-year harvest cycle and their environmental impact, particularly GHG emissions depending on the transport distance adopted. Another goal was to identify the links (processes) with the most negative impact on the environment.

The environmental impact of a specific amount of biomass supplied to an integrated multi-product biorefinery was analysed. One milligram of dry willow chips was determined as the main functional unit in the system under study. This unit is useful in the analysis of willow biomass utilisation in varied conversion technologies to obtain different products in an integrated biorefinery.

Due to the wide-ranging nature of the study, the data on emissions per one hectare of the plantation are provided in Appendix Table 6 and allow calculations for each functional unit.

\section{System Description}

The willow production process until the biorefinery gate was adopted as the system boundary (Fig. 1). The preparation activities performed on the willow cultivation fields included spraying with Roundup360 SL (1.44 $\mathrm{kg} \mathrm{ha}^{-1}$ of gliphosate), disking, winter ploughing, fertilisation with $300 \mathrm{~kg} \mathrm{ha}^{-1}$ of PRP Sol (a calcium and magnesium fertilizer mixed with minerals specific to PRP technology and agglomerated by a soluble plant-based binder - lignosulphonate), harrowing, mechanical planting of willow cuttings with a step planter, spraying with a soil herbicide Guardian CompleteMix $664 \mathrm{SE}$ (1.58 $\mathrm{kg}^{1}$ of acetochlor), mechanical weeding and spraying with a herbicide against monocotyledon weeds Targa Super $\left(0.13 \mathrm{~kg} \mathrm{ha}^{-1}\right.$ of quizalofop- $P$ ethyl). Before the beginning of the second year of growth, mineral fertilisation was performed at: $\mathrm{N}: 90 \mathrm{~kg} \mathrm{ha}^{-1}$ (as ammonium nitrate), $\mathrm{P}_{2} \mathrm{O}_{5}: 30 \mathrm{~kg} \mathrm{ha}^{-1}$ (as triple superphosphate) and $\mathrm{K}_{2} \mathrm{O}$ : $60 \mathrm{~kg} \mathrm{ha}^{-1}$ (as potassium chloride). Then, fertilisation treatments at the abovementioned doses were applied following each harvest of crops. Throughout the period of the use of the plantation, a total of seven fertilisation treatments were applied.

After the third year of growth, willow crops were harvested with a single stage harvester Claas Jaguar 830 with a header dedicated for energy crops. Chips were collected from the harvester with three New Holland TM 130 tractors with T 169/2 trailers. Willow chips were transported to the farmstead, where they were unloaded. They were then loaded (with a Manitou Scopic MLT 735 telescopic loader) onto trucks and transported to the conversion plant. The road transport was conducted with $80 \mathrm{~m}^{3}$ containers, which totalled 25 tonnes of fresh chips per run. Three road transport distances were adopted: 25,50 and $100 \mathrm{~km}$. The same distance after biomass unloading was added. Although it is assumed that biomass transport should not exceed approx. $30 \mathrm{~km}$, transporting it to a distance exceeding $200 \mathrm{~km}$ is often cost-effective. Therefore, for practical reasons, longer transport distances were also analysed. It was assumed that the plantation would be operated for 21 years, and the plants would be harvested in seven cycles every 3 years. The plantation was liquidated (re-established) after 21 years of operation. The SRWC willow plantation liquidation involved mechanical desintegration of root stocks remaining over the plantation area using a New Holland TM 175 HP tractor with a rototiller.

The amount harvested in the first year and in the other years was assumed to be the same. Our multi-year studies have shown that an increase in yield is achieved in the second and third cycle of willow harvest. However, the yield may 


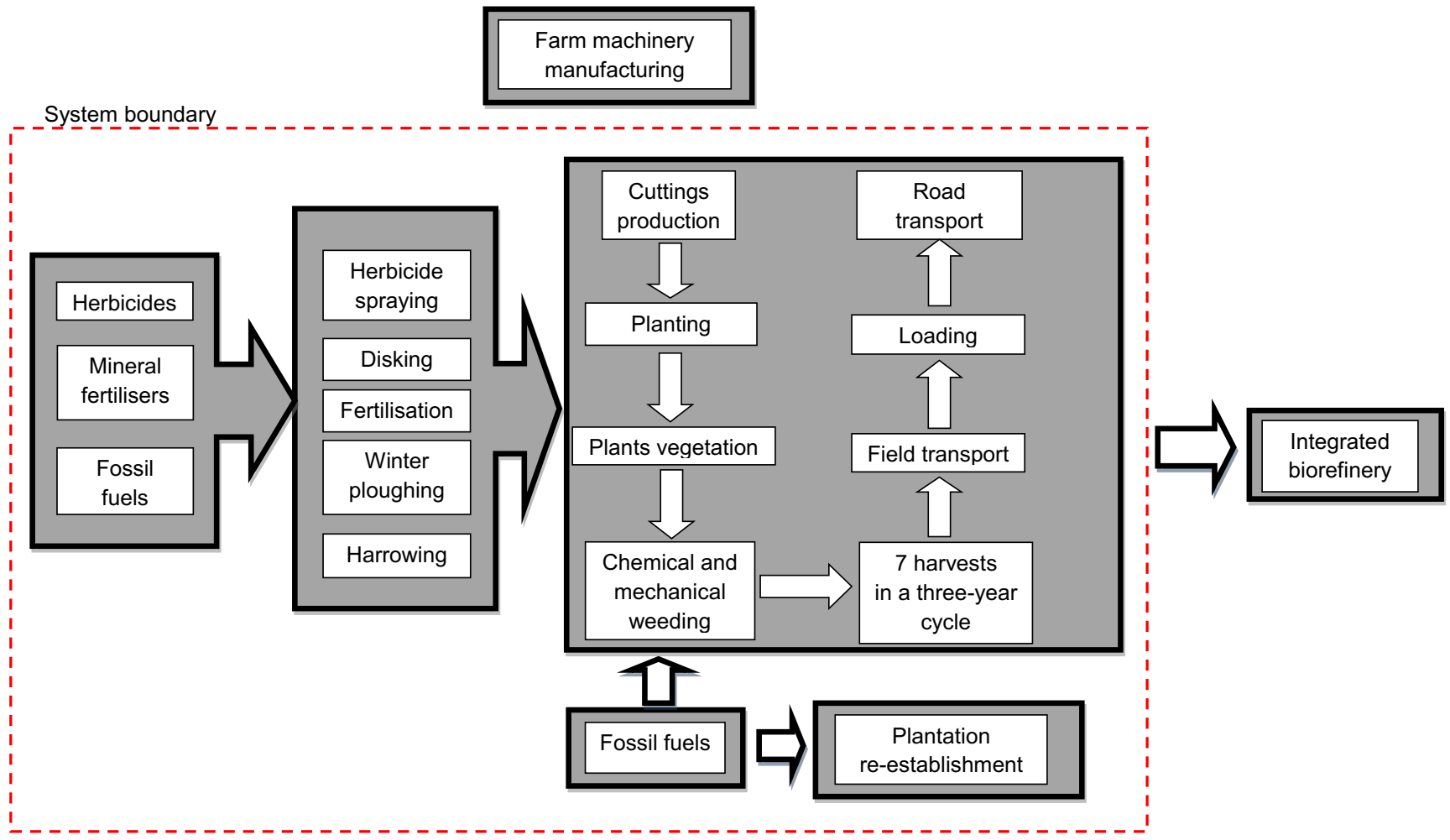

Fig. 1 Boundaries of the study system

decrease in subsequent (4-7) harvest cycles due to the accumulation of diseases, pests and plant mortality [35]. In consequence, mean biomass yield in subsequent harvest cycles is similar to the first harvest cycle. The average dry matter yield in the first rotation was $21.8 \mathrm{Mg} \mathrm{ha}^{-1}$. The highest biomass and energy yield was obtained from the cultivar UWM 006, and the lowest yield was from UWM 155 (Table 1) [35].

The willow chips production data for the 3-year cycle was based mainly on the author's studies, the EcoInvent 2.2 database and additional estimation data and surveys. The technical and operational parameters of agricultural machines were based on our research and the data contained in the catalogue of agricultural machines [36] and in materials published by manufacturers of tractors and machines. Detailed sources of the above data were included in Tables 2 and 3. The study took into account the environmental impact of emissions from the production process of herbicides, mineral fertilisers, fuels (data from EcoInvent) and emissions resulting from the application of nitrogen and phosphorus fertilisers (data from literature, described in detail further in the method section). The system boundaries also included the amount of carbon bound in the soil in the process of growing SRWC willow (data from literature; the methods are described further in the method section). The study did not take into account the environmental impact of the production of agricultural machines and equipment due to their low impact on LCA. This assumption is based on the completed LCA analyses which show that the impact of the production of these machines on the analysis is negligible compared to their exploitation. However, the production and use of road transport vehicles were included in the analysis due to the effect of their impact, not only on the services, but also on road construction and renovation (emission based on EcoInvent).

\section{Organic Carbon}

The amount of carbon bound in the soil in the process of growing perennial energy crops is estimated at 0.33 to $2.27 \mathrm{Mg} \mathrm{CO}_{2}$ eq. ha year ${ }^{-1}$, depending on the plant species, harvest cycle, agrotechnical procedures, etc. [25, 37, 38]. The amount of sequestered carbon was found to be closely linked to the yield

Table 1 Dry matter yield ( $\mathrm{Mg} \mathrm{ha}^{-1}$ d.m.) and yield energy value (GJ $\mathrm{ha}^{-1}$ ) of willow cultivars obtained in a 3-year harvest cycle [35]

\begin{tabular}{lll}
\hline Cultivar & $\begin{array}{l}\text { Dry biomass yield } \\
\left(\mathrm{Mg} \mathrm{ha}^{-1} \mathrm{~d} . \mathrm{m} .\right)\end{array}$ & $\begin{array}{l}\text { Yield energy value } \\
\left(\mathrm{GJ} \mathrm{ha}^{-1}\right)\end{array}$ \\
\hline Start & $20.3 \pm 2.5 \mathrm{c}$ & $344.6 \pm 44.6 \mathrm{c}$ \\
Tur & $11.0 \pm 0.9 \mathrm{e}$ & $191.6 \pm 15.3 \mathrm{e}$ \\
Turbo & $20.3 \pm 2.5 \mathrm{c}$ & $341.5 \pm 43.6 \mathrm{c}$ \\
UWM 006 & $42.7 \pm 2.5 \mathrm{a}$ & $727.4 \pm 43.4 \mathrm{a}$ \\
UWM 035 & $15.1 \pm 2.2 \mathrm{~d}$ & $259.7 \pm 37.5 \mathrm{~d}$ \\
UWM 043 & $34.5 \pm 4.3 \mathrm{~b}$ & $585.4 \pm 72.1 \mathrm{~b}$ \\
UWM 155 & $8.4 \pm 0.4 \mathrm{e}$ & $138.8 \pm 6.7 \mathrm{e}$ \\
Mean & $21.8 \pm 12.0$ & $369.9 \pm 204.6$ \\
\hline
\end{tabular}

Mean \pm standard deviation; $\mathrm{a}, \mathrm{b}, \mathrm{c} . \mathrm{.}$ homogenous groups 
$[38,39]$. Consequently, it was assumed that the amount of sequestered carbon for different cultivars of short-rotation willow would correspond to the values noted by Grogan and Matthews [39], who found that carbon sequestration increases proportionally to the willow biomass yield. Thus, the assumed level of sequestration was from $0.37 \mathrm{Mg} \mathrm{ha}^{-1}$ year $^{-1} \mathrm{CO}_{2}$ eq. for the lowest yield (8.4 $\mathrm{Mg} \mathrm{ha}^{-1}$ d.m.) to $0.73 \mathrm{Mg} \mathrm{CO}_{2}$ eq. for the highest yield $\left(42.7 \mathrm{Mg} \mathrm{ha}^{-1} \mathrm{~d}\right.$.m.). These figures are close to those obtained in Poland [38].

Moreover, since carbon bound in plant litter (fallen leaves) and roots are mineralised within a short time [40, 41], it was assumed that the amount of organic carbon bound in soil during the period of the operation of the plantation should be decreased by the amount of organic carbon mineralised from crops' parts. It was adopted based on studies conducted in Poland which found that $42 \%$ of biomass from leaves and roots is permanently bound in soil [41].

\section{Emissions from the Utilisation of Nitrogen and Phosphorus Fertilisers}

Nitrous oxide emissions from the use of mineral fertilisers, according to IPCC [42], may range from 0.25 to $2.25 \%$ of the $\mathrm{N}$ in the fertiliser used. The default recommended value is $1.25 \%$. However, according to some studies, emission of this gas may be several times higher than the value recommended by IPCC [43]. Therefore, in order to avoid underestimation of this factor in the study, an upper limit of $2.25 \% \mathrm{~N}_{2} \mathrm{O} \mathrm{kg} \mathrm{N}{ }^{-1}$ from the mineral nitrogen fertiliser was adopted. Emission of ammonia to the atmosphere from the nitrogen fertiliser was based on the ECETOC report [44], in which the average emission was $2 \%$ $\mathrm{NH}_{3} \mathrm{~kg} \mathrm{~N}^{-1}$. Emission of nitrates caused by the leaching of nitrogen from mineral fertilisers was taken at $14 \% \mathrm{NO}_{3}^{-} \mathrm{kg}$ $\mathrm{N}^{-1}$, and leaching of phosphates at $1 \% \mathrm{PO}_{4}{ }^{2-} \mathrm{kg} \mathrm{P}^{-1}$ [45].

\section{Life Cycle Impact Assessment}

The life cycle impact assessment of willow cultivation was determined by the CML 2 baseline 2000 method, of which 6 categories of environmental impact were selected. Considering the volume of the manuscript, the authors present the categories which, according to the authors, are important for SRWC plant cultivation and have an effect on agricultural areas. Similar assumption was made by other authors [24, $46,47]$. The results for the other categories were included in Appendix Table 6. Selected categories are:

1. Abiotic depletion: This impact category indicator is related to extraction of minerals and fossil fuels due to inputs in the system (fuels production and use, mineral fertilizers production, plant protection products production, etc.).

2. Acidification: This category includes substances with a wide range of impact on soil, groundwater, surface water, 


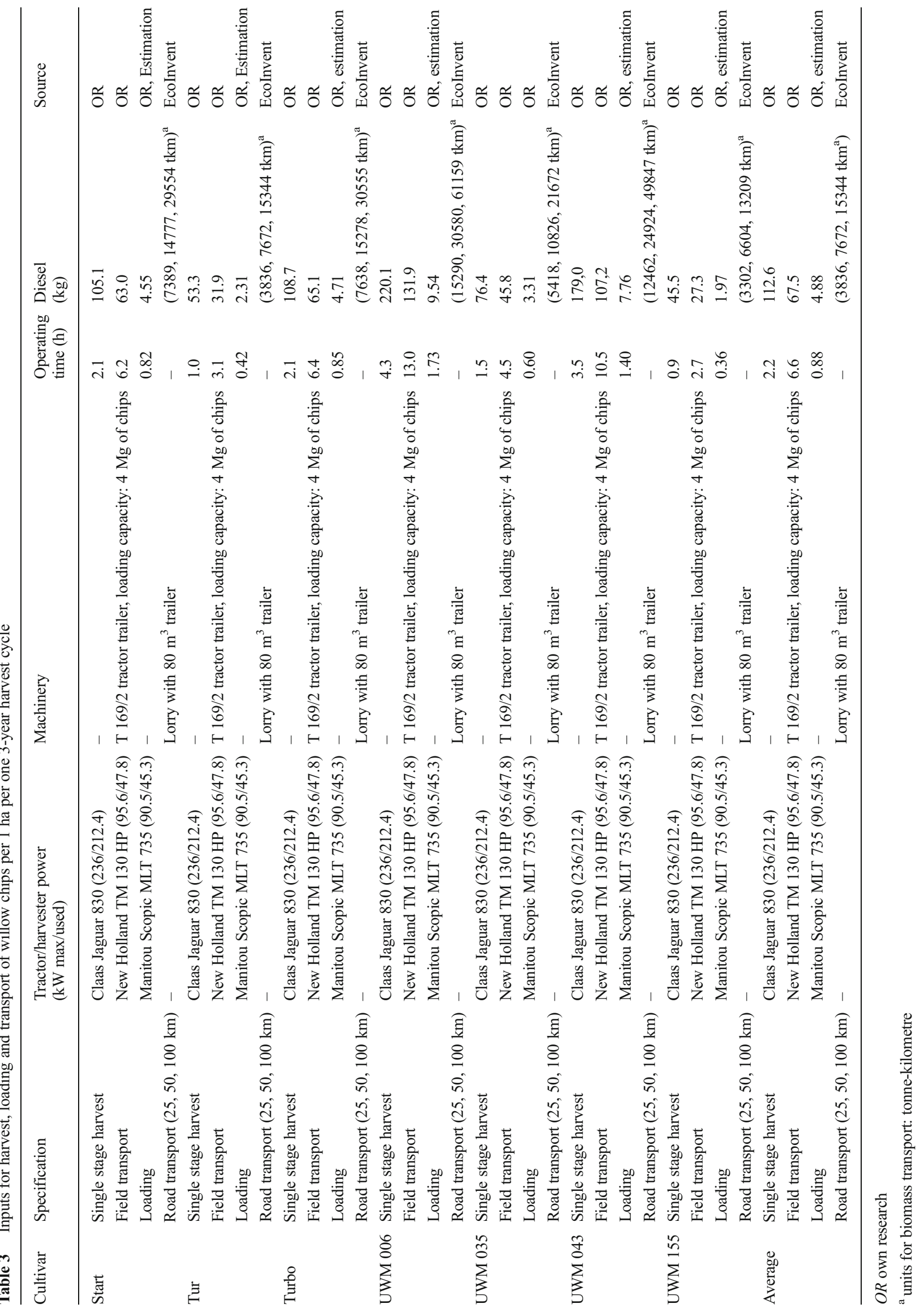


organisms, ecosystems and materials (buildings). Agricultural production contributes to acidification due to the use of mineral fertilisers.

3. Eutrophication (also known as nutrification) includes all effects due to excessive levels of macronutrients in the environment caused by emissions of nutrients to air, water and soil. Here, agricultural production has a strong impact through the use of fertilisers being rich in nitrogen and phosphorus as well as due to the runoff of these components to waters and the eutrophication thereof.

4. Global warming (GWP 100) is related to the emission of greenhouse gases and is expressed as global warming potential for a 100-year time horizon (GWP100). This indicator is, in this study, very important in view of the determination as to whether or not willow chips may meet the conditions set out for renewable biomass materials.

5. Freshwater aquatic ecotoxicity: This category indicator refers to the impact on freshwater ecosystems, as a result of the emission of toxic substances to air, water and soil. The use of production resources, i.e. plant protection products, fertilisers and fuels, may exert a direct impact on both aquatic and terrestrial biota (this also concerns the next point, 'terrestrial ecotoxicity').

6. Terrestrial ecotoxicity: This category refers to the impact of toxic substances on terrestrial ecosystems as a result of the emission of toxic substances [48].

After entering inputs and outputs to the SimaPro 7.3.2 program (classification), calculations were made of the environmental impact (characterisation). In order to compare the environmental impact of individual categories, normalisation was applied.

The environmental impact scores of LCA are often presented in units that are difficult to understand and compare. One easier way to interpret such scores is to normalise them, i.e. by dividing received scores by a reference scores. All impacts from different categories such as climate change, eutrophication, acidification, etc. are compared, for example, to the annual impact on an average citizen. Thus, normalisation gives an idea of an impact's magnitude.

Normalisation is regarded as optional for simplified LCA, but mandatory for detailed LCA. For each baseline indicator, normalisation scores are calculated for the reference situations. For this purpose, the normalisation result 'world 1990', based on emissions in 1990, was used. The normalised result for a given impact category and region is obtained by multiplying the characterisation factors by their respective emissions. The sum of these products in every impact category gives the normalisation factor (impact per 1 world citizen). When interpreting the results of this study, it should be remembered that the impact categories are based on the indicators rather than real measured emissions to the environment. Real emissions could differ from the assumed indicators since they depend on such factors as soil type, climate, temperature, level of ground waters, terrain relief, type of cultivation, etc. Thus, although these assessments can be beneficial, the results also need to be interpreted with caution.

\section{Results and Discussion}

\section{Characterisation and Normalisation}

Comparative characteristics of the production and road transport (distance of $25 \mathrm{~km}$ ) of 1 tonne of dry willow chips for the minimum (cultivar UWM 155), maximum (cultivar UWM 006) and average (of all the seven cultivars) yield have shown that the cultivar with the lowest yield has the highest impact on the environment (Table 4). Therefore, one may claim that the contribution and level of environmental impact of different stages of willow biomass production process changes with the level of yield. The impact of production of $1 \mathrm{Mg}$ d.m. of chips of cultivar UWM 006 was 2 to 3 times lower than that of cultivar UWM 155.

An analysis of the characterisation of the production of 1 tonne of dry chips for an average yield reveals a high contribution of mineral fertilisation (Fig. 2). Nitrogen fertilisation (ammonium nitrate) alone accounted for $29 \%$ in the abiotic depletion category and to $59 \%$ for global warming. When we include phosphorus fertilisers (triple superphosphate) and potassium fertilisers (potassium chloride), the figures increased to 38 and $74 \%$, respectively. A single stage harvest with a combine harvester had a considerable contribution, although not as high compared as mineral fertilisation. It was considerable for abiotic depletion (30\%), acidification (28\%) and global warming (18\%). Moreover, road transport had a significant contribution to abiotic depletion (15\%) and freshwater aquatic ecotoxicity (11\%). Figure 3 shows a positive effect of organic carbon sequestration in soil under the willow plantation on reducing global warming (by $67 \%$ ).

The level of emissions converted to $1 \mathrm{Mg}$ d.m. of willow chips transported to a biorefinery not only affected the level of environmental emissions (Table 4), but also the percentage contribution of different stages of production. Figure 3 shows the results of the characterisation of the effect of different stages of willow production in the production of cultivar UWM 155 (minimal yield) and Fig. 4 for cultivar UWM 006 (maximal yield). The inputs for setting up and running the plantation per $1 \mathrm{Mg}$ d.m. were comparable, both for the minimal and the maximal yield. This did not include $\mathrm{N}$ and PK fertilisation, whose contribution was much higher in the production of cultivar UWM 155. The procedures accounted for $29 \%$ in freshwater ecotoxicity and up to $85 \%$ for eutrophication. On the other hand, the figures for UWM 006 were 15 and $62 \%$ respectively. Moreover, a much higher input in willow chip production processes was recorded for a cultivar which gives a 
Table 4 Emissions to the environment in different impact categories converted to $1 \mathrm{Mg}$ d.m. at the minimal, maximal and average yield

\begin{tabular}{llccc}
\hline Impact category & Unit & Minimal yield & Maximal yield & Average yield \\
\hline Abiotic depletion & $\mathrm{kg} \mathrm{Sb}$ eq. & 0.744 & 0.313 & 0.412 \\
Acidification & $\mathrm{kg} \mathrm{SO}_{2}$ eq. & 1.189 & 0.407 & 0.588 \\
Eutrophication & $\mathrm{kg} \mathrm{PO}_{4}{ }^{3-}$ eq. & 0.607 & 0.162 & 0.266 \\
Global warming (GWP100) & $\mathrm{kg} \mathrm{CO}_{2}$ eq & 97.33 & 19.01 & 35.97 \\
Fresh water aquatic ecotox. & $\mathrm{kg} \mathrm{1.4-DB} \mathrm{eq.}$ & 14.92 & 4.50 & 6.92 \\
Terrestrial ecotoxicity & $\mathrm{kg} \mathrm{1.4-DB} \mathrm{eq.}$ & 0.487 & 0.139 & 0.220 \\
\hline
\end{tabular}

higher yield, which was associated with much higher inputs in single stage harvesting and biomass transport. For example, the contribution to a single stage harvest, as well as field and road transport, was up to three times higher for UWM 006 than for UWM 155. A comparison of the effect of organic carbon sequestration in soil on a reduction of GHG emission in the global warming category showed that it was lower for the minimal yield (58\%) than for the maximal yield (73\%). A greater reduction of GHG emissions for UWM 006 was attributed to a higher dry matter yield on the plantation area.

Characterisation does not give a full answer to which categories of the CML 2 baseline 2000 have the greater negative impact on the environment. Therefore, an additional LCIA parameter was used - normalisation (Fig. 5). Its result for the average (transport distance $25 \mathrm{~km}$ ) yield showed that freshwater toxicity had the greatest impact on the environment. The effect for abiotic depletion was also high, but it was lower by $22 \%$. It is noteworthy that the global warming category had the lowest environmental impact due to high organic carbon sequestration in soil on the willow plantation. Therefore, it can be concluded that the production of willow chips does not have as strong an impact on GHG emission as on other environmental factors associated with consumption of means of production, i.e. mineral fertilisers, pesticides and fossil fuels.

When considering the above values in terms of the impacts per capita in 1990, it can be concluded that they are very low and range from $0.000000012 \%$ of the climate change impact to the highest value of $0.000000051 \%$ for freshwater ecotoxicity impact per capita in the year 1990. It can therefore be stated that the effect of the willow cultivation system is virtually insignificant per capita in the year 1990. Certainly, if more recent methods for standardisation were employed, e.g. the latest ILCD method based on the data for EU-27 from 2010, these results would be different. For example, since 1990, the emission of greenhouse gases has increased, while the number of inhabitants in the EU has not changed significantly. This could increase the impact per capita. One can also assume that the impact of freshwater ecotoxicity per an average EU-27 citizen in 2010 will be less significant due to the use of less production resources manufactured in an energy
Fig. 2 Results of the characterisation of different production and transport stages for the average yield of willow at a distance of $25 \mathrm{~km}$. 1 Chemical weeding (1), 2 disking, 3 winter ploughing, 4 fertilisation PRP, 5 harrowing, 6 cuttings preparation, 7 planting, 8 chemical weeding (2), 9 mechanical weeding, 10 chemical weeding (3), 11 fertilisation $\mathrm{N}, 12$ fertilisation $\mathrm{PK}$, 13 chemical weeding (4), $14 \mathrm{C}$ sequestration, 15 harvest, 16 field transport, 17 loading chips, 18 road transport, 19 plantation reestablishment

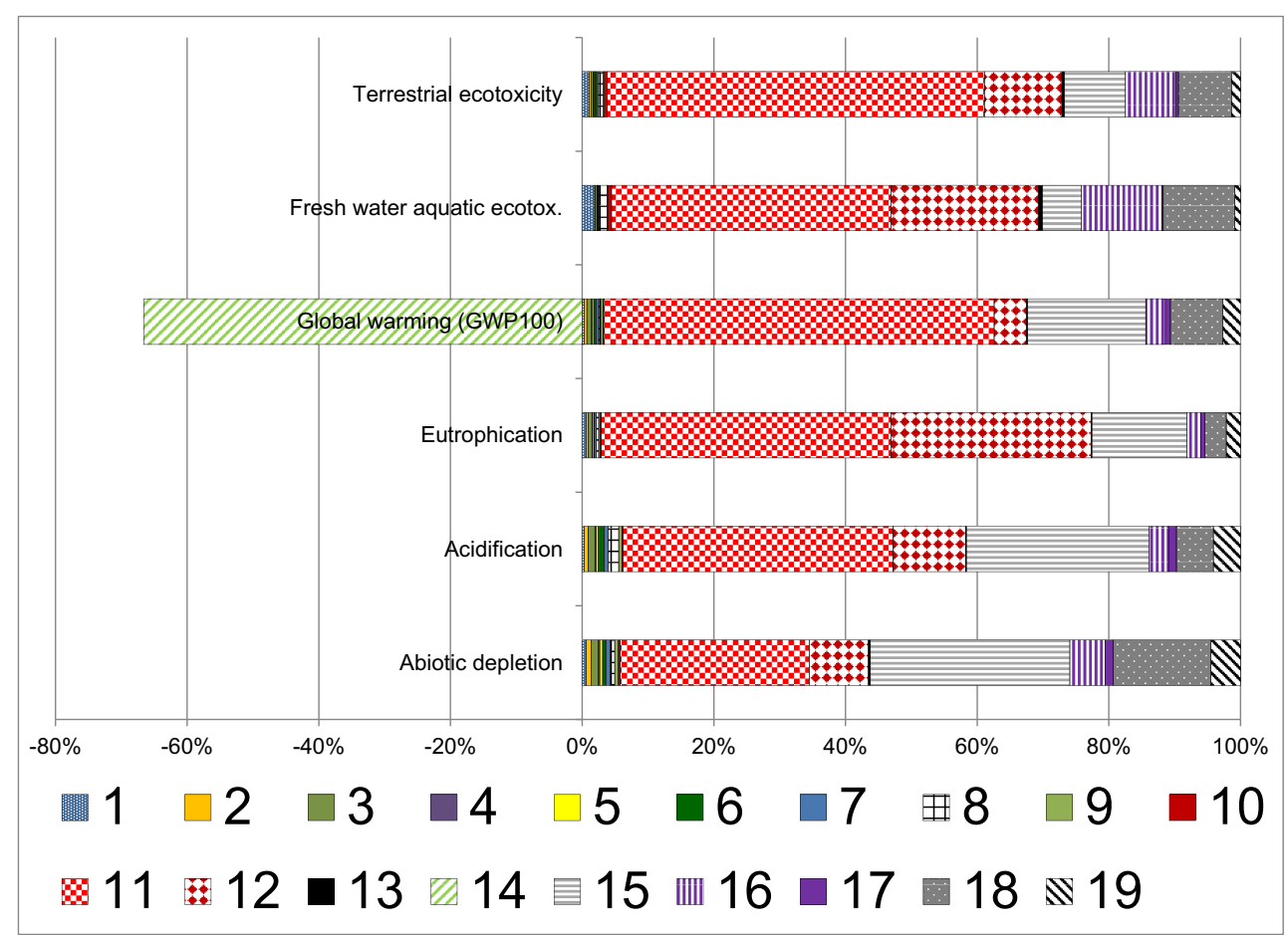


Fig. 3 Characterisation of different stages of production and transport of the minimal yield of willow (cultivar UWM 155) at a distance of $25 \mathrm{~km}$. Legend as in Fig. 2

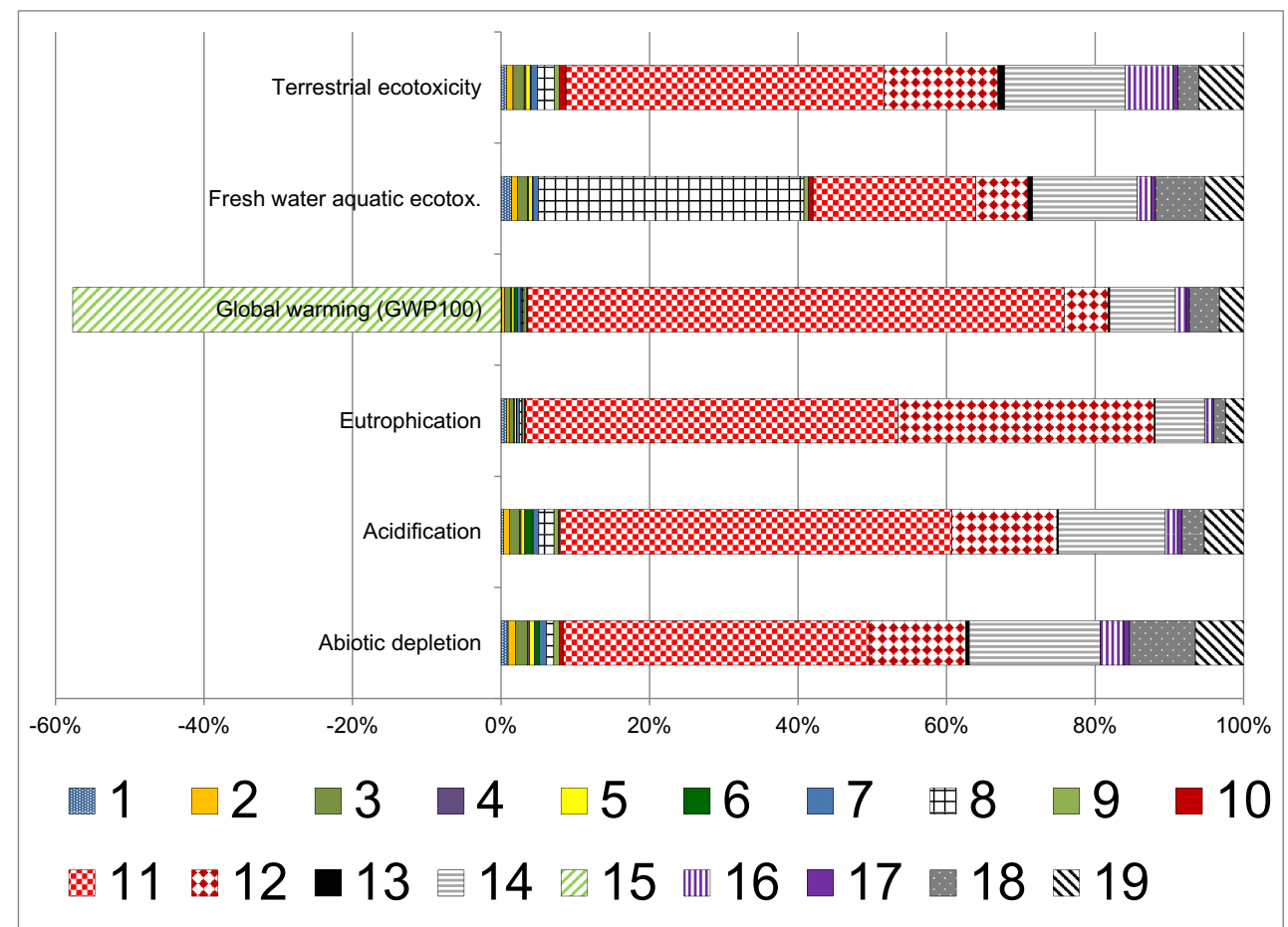

efficient manner, and being less toxic to the environment. Obviously, these considerations require further research.

These results are consistent with the earlier findings of these authors in willow production in 1- and 3-year harvest cycles, and they confirmed that production and use of mineral fertilisers are responsible for the majority of emissions in the impact categories under study. The contribution of NPK fertilisation, in the global warming category, was as high as $84 \%$ in the 1-year and $70 \%$ in the 3-year harvest cycle [29]. Similarly, in a study by Gasol et al. [49] on the poplar bioenergy system, the greatest environmental impacts were associated with the manufacturing and use of fertilisers, representing 51$67 \%$ in the following categories: global warming,
Fig. 4 Characterisation of different stages of production and transport of the maximal yield of willow (cultivar UWM 006) at a distance of $25 \mathrm{~km}$. Legend as in Fig. 2

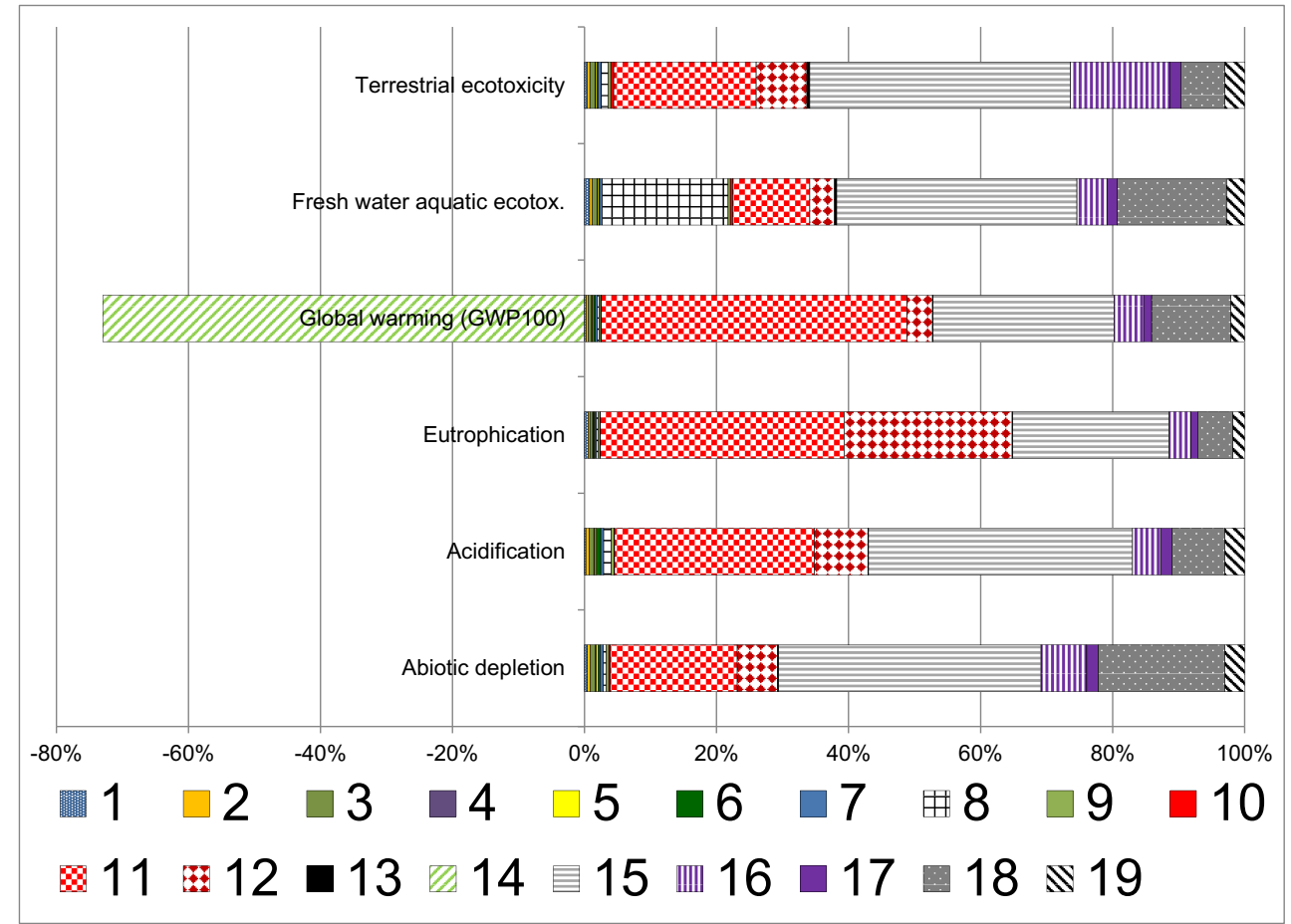


Fig. 5 Normalisation (World 1990) of different stages of production and transport of the average yield of willow at a distance of $25 \mathrm{~km}$

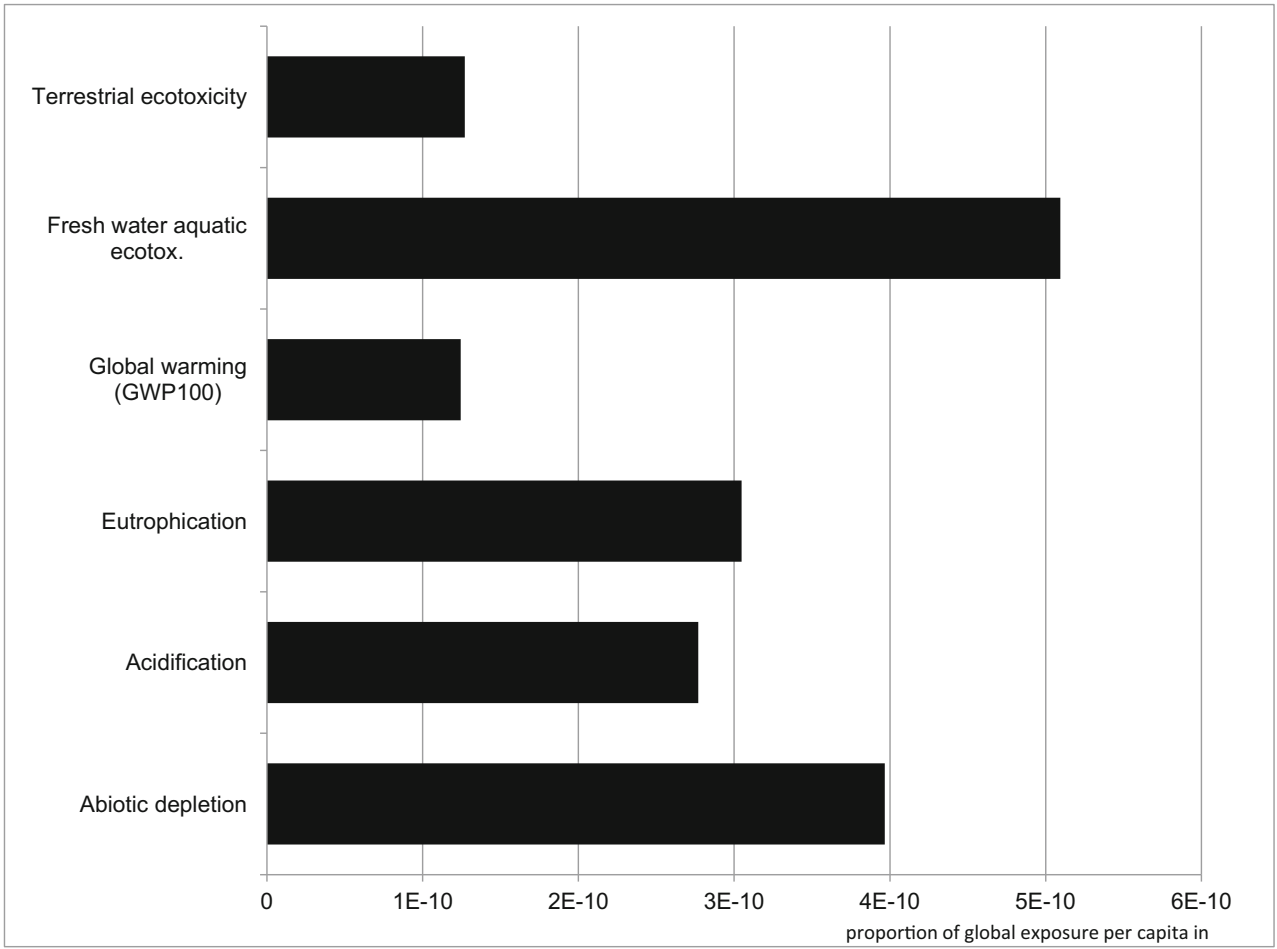

freshwater aquatic ecotoxicity, marine aquatic ecotoxicity and terrestrial ecotoxicity. González-García et al. [50] found a high impact of willow nitrogen fertilisation in the production of electricity. It accounted for $56 \%$ in the eutrophication category. Moreover, a high environmental impact of acidification was reported [51]. The impact of the process was nearly three times higher than that of eutrophication. Short rotation woody crops, such as willow, have a lower or similar environmental impact compared to other perennial energy crops. Their impact is even 2-3 times lower than annual crops, grown for food or as feedstock in energy generation or for industry [25, 51-53]. However, optimisation of the production of willow for biorefineries should be continued because, according to González-García et al. [50], the production of willow chips for bioethanol was the main source of impact concerning abiotic depletion, eutrophication, ozone layer depletion and cumulative energy demand.

Unfortunately, the system of subsidising of traditional agriculture in the European Union encourages the use of technologies oriented towards maximising yield per ha and increasing farm areas, which results in higher profits by farmers. Production becomes increasingly intensified, resulting in higher environmental impact [54]. For example, only $30-50 \%$ of the components of nitrogen fertilisers and $45 \%$ of those of phosphorus ones are used by a crop. The remaining nutrients are removed to water, soil and air. Poland, where these studies of LCA in willow production were conducted, is responsible for $30 \%$ of direct emissions of nitrogen and phosphorus to the Baltic Sea. One of the main causes for the poor condition of the Baltic is agriculture [55], which supplies about $40 \%$ of the nitrogen load and $50 \%$ of the phosphorus load. Moreover, acidification is also regarded as a process for limiting plant production in Poland and having an impact on the environment [56]. Therefore, according to the authors, the replacement of the annual plants cultivated for chemical and energy purposes with SRWC plants may result in lower emissions of nutrients and, thus, in lower environment eutrophication and acidification.

\section{Global Warming}

The emission of GHG from production and transport of willow chips, without carbon sequestration, amounted to $107.66 \mathrm{~kg} \mathrm{CO} 2$ eq. $\mathrm{Mg}^{-1}$ d.m. on average in road transport for $25 \mathrm{~km}$ (Table 5). The lowest values of GHG emissions were recorded for high-yielding cultivars, such as UWM 006 and UWM 043 (70.33 and $79.70 \mathrm{~kg} \mathrm{CO}$ eq. $\mathrm{Mg}^{-1}$ d.m.). A high level of GHG emission was determined for the cultivars of Tur and UWM 155. Based on the above data, it could be concluded that for higher yields of biomass obtained with an properly selected willow cultivar, with the same investment into the establishment of a plantation and a larger investment into biomass harvest (when compared with lowyielding cultivars), the biomass transportation results in greater limitations of GHG emissions. 
Table 5 Greenhouse gas emissions of $1 \mathrm{Mg}$ of dry willow chips depending on the transport distance

\begin{tabular}{|c|c|c|c|}
\hline \multirow[t]{2}{*}{ Cultivar } & \multirow[t]{2}{*}{ Distance $(\mathrm{km})$} & \multicolumn{2}{|c|}{ GHG emission ( $\mathrm{kg} \mathrm{CO}_{2}$ eq. $\mathrm{Mg}^{-1}$ d.m.) } \\
\hline & & $\begin{array}{l}\text { Without } \\
\text { sequestration }\end{array}$ & $\begin{array}{l}\text { With } \\
\text { sequestration }\end{array}$ \\
\hline UWM 155 (minimal yield) & 25 & 229.95 & 97.33 \\
\hline UWM 043 & & 79.70 & 23.17 \\
\hline UWM 035 & & 140.18 & 50.95 \\
\hline UWM 006 (maximal yield) & & 70.33 & 19.01 \\
\hline Turbo & & 114.01 & 37.31 \\
\hline Tur & & 179.63 & 65.29 \\
\hline Start & & 113.14 & 36.29 \\
\hline Average & & 107.66 & 35.97 \\
\hline UWM 155 (minimal yield) & 50 & 240.10 & 107.48 \\
\hline UWM 043 & & 88.21 & 31.69 \\
\hline UWM 035 & & 148.62 & 59.40 \\
\hline UWM 006 (maximal yield) & & 78.77 & 27.46 \\
\hline Turbo & & 122.86 & 46.17 \\
\hline Tur & & 187.84 & 73.50 \\
\hline Start & & 121.72 & 44.88 \\
\hline Average & & 116.23 & 44.54 \\
\hline UWM 155 (minimal yield) & 100 & 258.71 & 126.09 \\
\hline UWM 043 & & 48.73 & 48.73 \\
\hline UWM 035 & & 165.51 & 76.29 \\
\hline UWM 006 (maximal yield) & & 95.67 & 44.36 \\
\hline Turbo & & 140.58 & 63.88 \\
\hline Tur & & 204.25 & 89.92 \\
\hline Start & & 138.89 & 62.04 \\
\hline Average & & 133.36 & 61.67 \\
\hline
\end{tabular}

An increase in the transport distance to $50 \mathrm{~km}$ resulted in an increase in GHG emission by an average of $8.57 \mathrm{~kg} \mathrm{CO} 2$ eq. $\mathrm{Mg}^{-1}$ d.m. and in transport for $100 \mathrm{~km}$ by $25.7 \mathrm{~kg} \mathrm{CO}$ eq. $\mathrm{Mg}^{-1}$ d.m.

After organic carbon sequestration in soil under the willow plantation was included in the calculations, the average $\mathrm{CO}_{2}$ emission was much lower $\left(35.97 \mathrm{~kg} \mathrm{Mg}^{-1}\right.$ d.m.) (Table 5), which gives only $2.12 \mathrm{~kg} \mathrm{CO}$ eq. per 1 GJ of energy in willow chips transported for $25 \mathrm{~km}$ (Fig. 6). The adopted model of carbon sequestration from willow biomass (litter and roots) assumed its increase with increasing biomass yield [36]; in consequence, the largest decrease in GHG emission was recorded for highyielding cultivars UWM 006 and UWM 043. It amounted to 19.01 and $23.17 \mathrm{~kg} \mathrm{CO} 2$ eq. $\mathrm{Mg}^{-1}$ d.m. and 1.12 and $1.37 \mathrm{~kg} \mathrm{CO}$ eq. per $1 \mathrm{GJ}$. The value of the index for the other cultivars ranged from 36.29 (start) to $97.33 \mathrm{~kg} \mathrm{CO}$ eq. $\mathrm{Mg}^{-1}$ d.m. (UWM 155), equivalent to 2.14 and $5.92 \mathrm{~kg} \mathrm{CO}_{2}$ eq. $\mathrm{GJ}^{-1}$. After the transport distance increased to $50 \mathrm{~km}$, GHG emissions increased on average by $24 \%$ (for the average yield) and ranged from 27.46 to $107.48 \mathrm{~kg} \mathrm{CO} \mathrm{CO}_{2}$ eq. $\mathrm{Mg}^{-1}$ d.m. (1.61-6.48 kg $\mathrm{CO}_{2}$ eq.
$\mathrm{GJ}^{-1}$ ). When the transport distance increased to $100 \mathrm{~km}$, the average value of the index increased twofold compared to the distance of $25 \mathrm{~km}$. A larger increase in the emission of $\mathrm{CO}_{2}$ equivalents was recorded for highyielding cultivars: over twofold for UWM 043 (yield $34.5 \mathrm{Mg} \mathrm{ha}^{-1} \mathrm{~d} . \mathrm{m}$ ) and UWM 006 (42.7 $\mathrm{Mg} \mathrm{ha}^{-1}$ d.m.); for the other cultivars, the increase ranged from $29 \%$ for UWM 155 (8.4 $\mathrm{Mg} \mathrm{ha}^{-1}$ d.m.) to $71 \%$ for Turbo (20.3 $\mathrm{Mg} \mathrm{ha}^{-1}$ d.m.). However, it must be pointed out that GHG emission for UWM 043 and UWM 006 is still low compared to emission for the lower-yielding cultivars transported for $25 \mathrm{~km}$ (Table 5, Fig. 6).

It is very important to minimise the effect of plantations on global warming, and this issue should be carefully considered in biomass production for biorefineries or for energy generation. These findings, as well as other studies, have shown that the emission of GHG from the production of SRWC is low. In previous studies by these authors, GHG emission amounted to $5.9 \mathrm{~kg} \mathrm{CO}_{2}$ eq. $\mathrm{GJ}^{-1}$ from biomass production in a 1-year harvest cycle and $0.8 \mathrm{~kg} \mathrm{CO}_{2}$ eq. $\mathrm{GJ}^{-1}$ in 3-year harvest cycle [29]. Similar results were obtained by Heller et al. [40], where 
Fig. 6 Greenhouse gas emissions ( $\mathrm{kg} \mathrm{CO}_{2}$ eq.) per $1 \mathrm{GJ}$ of energy in willow chips depending on the transport distance



emissions for a 3-year harvest cycle amounted to $0.68 \mathrm{~kg}$ $\mathrm{CO}_{2}$ eq. $\mathrm{GJ}^{-1}$. On the other hand, GHG emission from the production of willow examined by Brandao et al. [25] was similar $\left(2.6 \mathrm{~kg} \mathrm{CO}_{2}\right.$ eq. $\left.\mathrm{GJ}^{-1}\right)$. The latest American studies have shown that $\mathrm{GHG}$ emission can even be negative (from -2.7 to $-6.9 \mathrm{~kg} \mathrm{CO}$ eq. $\mathrm{GJ}^{-1}$ [31], which is caused by large carbon sequestration in soil and lower demand for fuels than in this study. These differences in emission usually depend on the adopted methodology. According to the review of Djomo et al. [57] on LCA in production of poplar and willow, GHG emission to farm gate in different studies ranged from 0.6 to $10.6 \mathrm{~kg} \mathrm{CO}_{2}$ eq. $\mathrm{GJ}^{-1}$. Emission in those studies was $1.12,1.61$ and $2.60 \mathrm{~kg}$ $\mathrm{CO}_{2}$ eq. $\mathrm{GJ}^{-1}$ in the production of willow chips and their transport for 25, 50 and $100 \mathrm{~km}$, respectively.

Since the aim of the paper was a life cycle assessment of lignocellulose material used mainly for chemical purposes, the main functional unit was willow dry matter ( $1 \mathrm{t} \mathrm{d} . \mathrm{m}$.). In this way, the LCA of willow production and transportation could be compared with other raw materials used in integrated biorefineries. Nevertheless, some of the raw material may be used for more traditional purposes such as electricity or heat production instead of fossil fuels, e.g. natural gas, heating oil and hard coal.

Greenhouse gas emission from only burning of natural gas (excluding its extraction, transport, etc.), which is regarded as a clean fuel, is 23 times higher than that from willow growing system analysed in this study. Compared to heating oil and hard coal, willow cultivation is even more beneficial. GHG emission from only burning these fuels is, respectively, 30 and over 39 times higher than GHG emission from the entire willow production system and from willow burning [58].

Using willow biomass for the production of bioenergy as a substitute for energy produced from fossil fuels has a positive GHG balance and reduces the greenhouse effect $[59,60]$. A study of Kimming et al. [61] shows that production of heat and electricity for 150 household village in Sweden can reduce greenhouse gas emissions considerably compared to the natural gas-based system. Two willow systems emitted from 6 to 8 times less GHGs than natural gas-based system. In research of Styles and Jones [62], the biomass-based system emitted even much less GHGs compared to the fossil-based systems. Miscanthus and SRCW-based electricity production systems emitted 0.131 and $0.132 \mathrm{~kg} \mathrm{CO}^{2}$ eq. $\mathrm{kWh}^{-1}$ electricity, respectively, compared with 1.150 and $0.990 \mathrm{~kg} \mathrm{CO}^{2}$ eq. $\mathrm{kWh}^{-1}$ electricity for peat- and coal-based systems.

\section{Conclusions}

In the present study, an analysis was made of the environmental impact of the production and transport of SRWC willow as alternative feedstock for the production of energy, biofuels and bioproducts using the LCA method. Efforts can (and should be) made to reduce the contribution of the weak links of the life cycle, which have a detrimental impact on the environment. This study has 
revealed the high environmental impact of fertilisation, harvesting and transport of biomass, and the impact of the two latter factors is especially significant at high yields. A high impact of eutrophication was also observed, caused by the use of nitrogen and phosphorus fertilisers. This should be minimised due to the fact that Polish agriculture is largely responsible for pollution of the Baltic Sea. Since the production of plants such as SRWC willow does not require high levels of nitrogen or phosphorus fertilisation, these negative environmental effects of agriculture may also be limited.

A reduction in GHG emission could be achieved by using organic fertilisers instead of nitrogen-mineral fertilisers. Black et al. [63] found that this reduced the GHG emission by nearly $30 \%$ when converted to $1 \mathrm{Mg}$ d.m. of willow. Fuel consumption can be reduced, especially by more effective use of machines in harvest and better organisation of field transport.
Road transport of biomass had a considerable impact on environmental emissions, especially those of greenhouse gases. Therefore, only chips obtained from highyielding cultivars, i.e. UWM 006 and UWM 043, could be transported to longer distances of 50 and $100 \mathrm{~km}$ because their impact on global warming was much smaller than the low-yielding cultivars UWM 155, Tur and UWM 035 , even when biomass was transported for $100 \mathrm{~km}$. On the other hand, the justifiability of transport for such long distances should be considered because GHG emission increased significantly with increasing transport distance for high-yielding cultivars.

Acknowledgments The research leading to these results has received funding from the European Union Seventh Framework Programme (FP7/ 2007-2013) under grant agreement no. 241718 EuroBioRef.

\section{Appendix}

Table 6 Characterisation of production of willow chips (per 1 ha) for different cultivars and transport distances

\begin{tabular}{|c|c|c|c|c|c|c|c|c|c|c|c|c|c|c|}
\hline \multirow[t]{2}{*}{ Impact category } & \multicolumn{9}{|l|}{$25 \mathrm{~km}$} & \multicolumn{5}{|l|}{$50 \mathrm{~km}$} \\
\hline & $\begin{array}{l}\text { UWM } \\
155\end{array}$ & $\begin{array}{l}\text { UWM } \\
043\end{array}$ & $\begin{array}{l}\text { UWM } \\
035\end{array}$ & $\begin{array}{l}\text { UK } \\
006\end{array}$ & & Turbo & Tur & Start & Average & $\begin{array}{l}\text { UWM } \\
155\end{array}$ & $\begin{array}{l}\text { UWM } \\
043\end{array}$ & $\begin{array}{l}\text { UWM } \\
035\end{array}$ & $\begin{array}{l}\text { UWM } \\
006\end{array}$ & Turbo \\
\hline Abiotic depletionkg Sb eq & 43.60 & 81.73 & 52.42 & 93. & & 61.65 & 45.82 & 60.62 & 62.76 & 47.47 & 96.36 & 58.77 & 111.43 & 70.62 \\
\hline Acidification $\mathrm{kg} \mathrm{SO}_{2}$ eq & 69.68 & 109.34 & 78.85 & 121 & & 88.45 & 71.99 & 87.38 & 89.61 & 71.77 & 117.23 & 82.28 & 131.24 & 93.29 \\
\hline Eutrophication $\mathrm{kg} \mathrm{PO}_{4}{ }^{3-}$ eq & 35.58 & 45.32 & 37.83 & 48 & & 40.19 & 36.15 & 39.93 & 40.48 & 36.13 & 47.41 & 38.74 & 50.88 & 41.47 \\
\hline Global warming (GWP100) $\mathrm{kg} \mathrm{CO}_{2}$ eq & 5752.18 & 5596.46 & 5396.15 & 568 & .59 & 5312.17 & 5036.36 & 5156.96 & 5479.05 & 6297.35 & 7653.79 & 6290.61 & 8204.79 & 6573.26 \\
\hline Ozone layer depletion (ODP) kg CFC-11 eq & 0.00129 & 0.00215 & 0.00149 & 0.0 & 242 & 0.00170 & 0.00134 & 0.00167 & 0.00172 & 0.00137 & 7 0.00247 & 0.00163 & 0.00281 & 0.00190 \\
\hline Human toxicity $\mathrm{kg}$ 1.4-DB eq & 4520.78 & 7932.04 & 5309.90 & 898 & .41 & 6135.83 & 4719.99 & 6043.38 & 6235.33 & 4649.36 & 8417.24 & 5520.85 & 9578.72 & 6433.24 \\
\hline Fresh water aquatic ecotox. $\mathrm{kg}$ 1.4-DB eq & 874.33 & 1233.21 & 957.26 & 134 & .95 & 1044.24 & 895.25 & 1034.46 & 1054.67 & 922.02 & 1413.18 & 1035.51 & 1564.75 & 1154.55 \\
\hline Marine aquatic ecotoxicity kg 1.4-DB eq & 2220669 & 3049688 & 2412292 & 330 & 400 & 2613151 & 2269023 & 2590592 & 2637276 & 2324000 & $0 \quad 3439627$ & 2581827 & 3783830 & 2852174 \\
\hline Terrestrial ecotoxicity kg 1.4-DB eq & 28.52 & 38.48 & 30.83 & 41. & & 33.24 & 29.11 & 32.97 & 33.53 & 29.65 & 42.73 & 32.67 & 46.77 & 35.84 \\
\hline Photochemical oxidation $\mathrm{kg} \mathrm{C}_{2} \mathrm{H}_{4}$ & 1.276 & 2.193 & 1.488 & 2.4 & & 1.711 & 1.330 & 1.686 & 1.737 & 1.343 & 2.445 & 1.598 & 2.784 & 1.865 \\
\hline \multirow[t]{2}{*}{ Impact category } & \multicolumn{4}{|l|}{$50 \mathrm{~km}$} & \multicolumn{10}{|c|}{$100 \mathrm{~km}$} \\
\hline & Tur & Start 50 & Avera & & \multicolumn{2}{|c|}{ UWM 155} & UWM 043 & UWM 035 & \multicolumn{2}{|c|}{ UWM 006} & Turbo & Tur & Start & Average \\
\hline Abiotic depletionkg Sb eq & 50.32 & 69.29 & 72.04 & \multicolumn{3}{|c|}{55.22} & 125.61 & 71.49 & \multicolumn{2}{|c|}{147.32} & 88.54 & 59.33 & 86.63 & 90.59 \\
\hline Acidification $\mathrm{kg} \mathrm{SO}_{2}$ eq & 74.42 & 92.06 & 94.62 & \multicolumn{3}{|c|}{75.95} & 133.02 & 89.15 & \multicolumn{2}{|c|}{150.61} & 102.97 & 79.28 & 101.42 & 104.63 \\
\hline Eutrophication $\mathrm{kg} \mathrm{PO}_{4}{ }^{3-}$ eq & 36.79 & 41.16 & 41.80 & \multicolumn{3}{|c|}{37.24} & 51.58 & 40.55 & \multicolumn{2}{|l|}{56.00} & 44.02 & 38.07 & 43.63 & 44.44 \\
\hline Global warming (GWP100) $\mathrm{kg} \mathrm{CO}_{2}$ eq & 5669.65 & 6376.74 & 6784. & \multicolumn{3}{|c|}{7387.70} & 11768.44 & 8079.54 & \multicolumn{2}{|c|}{13253.20} & 9095.44 & 6936.23 & 8816.29 & 9394.07 \\
\hline Ozone layer depletion (ODP) kg CFC-11 eq & 0.00144 & 0.00187 & 0.001 & \multicolumn{3}{|c|}{0.00155} & 0.00312 & 0.00191 & \multicolumn{2}{|c|}{0.00361} & 0.00229 & 0.00164 & 0.00225 & 0.00234 \\
\hline Human toxicity $\mathrm{kg}$ 1.4-DB eq & 4869.34 & 6331.05 & 6543. & \multicolumn{3}{|c|}{4906.50} & 9387.64 & 5942.75 & \multicolumn{2}{|c|}{10769.33} & 7028.08 & 5168.05 & 6906.39 & 7158.65 \\
\hline Fresh water aquatic ecotox. kg 1.4-DB eq & 950.65 & 1141.16 & 1168.8 & \multicolumn{3}{|c|}{1017.39} & 1773.11 & 1191.99 & \multicolumn{2}{|c|}{2006.37} & 1375.18 & 1061.44 & 1354.56 & 1397.14 \\
\hline Marine aquatic ecotoxicity kg 1.4-DB eq & 2389055 & 2821785 & 28846 & & 2530 & 660 & 4219506 & 2920895 & 47406 & & 3330221 & 2629119 & 3284171 & 3379316 \\
\hline Terrestrial ecotoxicity kg 1.4-DB eq & 30.41 & 35.49 & 36.22 & & 31.9 & & 51.24 & 36.37 & 57.21 & & 41.06 & 33.03 & 40.53 & 41.62 \\
\hline Photochemical oxidation $\mathrm{kg} \mathrm{C}_{2} \mathrm{H}_{4}$ & 1.407 & 1.835 & 1.897 & & 1.47 & & 2.947 & 1.816 & 3.401 & & 2.173 & 1.562 & 2.133 & 2.215 \\
\hline
\end{tabular}


Open Access This article is distributed under the terms of the Creative Commons Attribution 4.0 International License (http:// creativecommons.org/licenses/by/4.0/), which permits unrestricted use, distribution, and reproduction in any medium, provided you give appropriate credit to the original author(s) and the source, provide a link to the Creative Commons license, and indicate if changes were made.

\section{References}

1. Witze A (2007) That's oil folks. Nature 445(4):14-17

2. BP (2013) BP Statistical Review of World Energy 2013. BP, London

3. EWG (2007) Coal: resources and future production. Energy Watch Group, Ottobrunn, EWG-Series No 1/2007

4. IPCC (2013) Climate change: the physical science basis. Intergovernmental Panel of Climate Change, New York

5. Watson RT, Albritton DL (2001) Intergovernmental Panel on Climate Change. Climate change 2001: synthesis report. Cambridge University Press, Cambridge

6. FitzPatrick M, Champagne P, Cunningham MF, Whitney RA (2010) A biorefinery processing perspective: treatment of lignocellulosic materials for the production of value-added products. Bioresour Technol 101(23):8915-8922

7. Zhang X, Tu M, Paice M (2011) Routes to potential bioproducts from lignocellulosic biomass lignin and hemicelluloses. Bioenerg Res 4(4):246-257

8. Sanna A (2014) Advanced biofuels from thermochemical processing of sustainable biomass in Europe. Bioenergy Res 7(1):36-47

9. Dumeignil F (2012) A new concept of biorefinery comes into operation: the EuroBioRef concept. In: Aresta M, Dibenedetto A, Dumeignil F (eds) Biorefinery. From Biomass to Chemicals and Fuels. Walter de Gruyter GmbH \& Co, Berlin/Boston, pp 1-17

10. Eurostat (2013) Energy, transport and environment indicators. doi: $10.2785 / 4663$

11. European Commission (2009) Directive 2009/28/EC of the European Parliament and of the Council of 23 April 2009 on the promotion of the use of energy from renewable sources and amending and subsequently repealing Directives 2001/77/EC and 2003/30/EC L 140/17, vol 2009/28/EC Official Journal of the European Union

12. U.S. Department of Energy (2004) Top value chemicals from biomass volume 1: Results of screening for potential candidates from sugars and synthesis gas. Department of Energy. http://www.dtic. mil/get-tr-doc/pdf?AD=ADA436528. Accessed 8 Aug 2014

13. García A, González Alriols M, Labidi J (2014) Evaluation of different lignocellulosic raw materials as potential alternative feedstocks in biorefinery processes. Ind Crop Prod 53:102-110

14. Stolarski MJ, Szczukowski S, Tworkowski J, Wroblewska H, Krzyzaniak M (2011) Short rotation willow coppice biomass as an industrial and energy feedstock. Ind Crop Prod 33(1):217-223

15. Stolarski MJ, Krzyzaniak M, Waliszewska B, Szczukowski S, Tworkowski J, Zborowska M (2013) Lignocellulosic biomass derived from agricultural land as industrial and energy feedstock. Drewno 189:5-23

16. Kajaste R (2014) Chemicals from biomass-managing greenhouse gas emissions in biorefinery production chains - a review. J Clean Prod 75:1-10

17. Krzyżaniak M, Stolarski MJ, Waliszewska B, Szczukowski S, Tworkowski J, Załuski D, Śnieg M (2014) Willow biomass as feedstock for an integrated multi-product biorefinery. Ind Crop Prod 58:230-237
18. Bullard MJ, Mustill SJ, Carver P, Nixon PMI (2002) Yield improvements through modification of planting density and harvest frequency in short rotation coppice Salix spp.-2. Resource capture and use in two morphologically diverse varieties. Biomass Bioenergy 22(1):27-39

19. Volk TA, Abrahamson LP, Nowak CA, Smart LB, Tharakan PJ, White EH (2006) The development of short-rotation willow in the northeastern United States for bioenergy and bioproducts, agroforestry and phytoremediation. Biomass Bioenergy 30(8-9):715-727

20. Ericsson K, Nilsson LJ (2006) Assessment of the potential biomass supply in Europe using a resource-focused approach. Biomass Bioenergy 30(1):1-15

21. Stolarski M, Szczukowski S, Tworkowski J, Klasa A (2008) Productivity of seven clones of willow coppice in annual and quadrennial cutting cycles. Biomass Bioenergy 32(12):1227-1234

22. Adegbidi HG, Volk TA, White EH, Abrahamson LP, Briggs RD, Bickelhaupt DH (2001) Biomass and nutrient removal by willow clones in experimental bioenergy plantations in New York State. Biomass Bioenergy 20(6):399-411

23. European Committee for Standardisation (2006) ISO 14040 Environmental management - Life cycle assessment Requirements and guidelines. CEN, Brussels

24. European Environment Agency (1998) Life Cycle Assessment (LCA): a guide to approaches, experiences and information sources. European Environment Agency. Environmental Issue Series no. 6

25. Brandao M, Mila i Canals L, Clift R (2011) Soil organic carbon changes in the cultivation of energy crops: implications for GHG balances and soil quality for use in LCA. Biomass Bioenergy 35(6): 2323-2336

26. Biswas WK, Graham J, Kelly K, John MB (2010) Global warming contributions from wheat, sheep meat and wool production in Victoria, Australia - a life cycle assessment. J Clean Prod 18(14): 1386-1392

27. Manfredi M, Vignali G (2014) LCA of a packaged tomato puree: a comparison of environmental impacts produced by different life cycle phases. J Clean Prod 73:275-284

28. Thevenot A, Aubin J, Tillard E, Vayssieres J (2013) Accounting for farm diversity in life cycle assessment studies - the case of poultry production in a tropical island. J Clean Prod 57:280-292

29. Krzyżaniak M, Stolarski M, Szczukowski S, Tworkowski J (2013) Life cycle assessment of willow produced in short rotation coppices for energy purposes. J Biobased Mater Bioenergy 7(5):566-578

30. Yan M-J, Humphreys J, Holden NM (2011) An evaluation of life cycle assessment of European milk production. J Environ Manag 92(3):372-379

31. Goglio P, Owende PMO (2009) A screening LCA of short rotation coppice willow (Salix sp.) feedstock production system for smallscale electricity generation. Biosyst Eng 103(3):389-394

32. Caputo J, Balogh S, Volk T, Johnson L, Puettmann M, Lippke B, Oneil E (2014) Incorporating uncertainty into a life cycle assessment (LCA) model of short-rotation willow biomass (Salix spp.) crops. Bioenergy Res 7(1):48-59

33. US Congress (2007) US Energy Investment and Security Act of 2007 (Pub. L. 110-140, subtitle A)

34. European Committee for Standardisation (2006) ISO 14044 Environmental management - Life cycle assessment - Principles and framework. CEN, Brussels

35. Stolarski MJ, Krzyżaniak M, Tworkowski J, Szczukowski S, Gołaszewski J (2014) Energy intensity and energy ratio in producing willow chips as feedstock for an integrated biorefinery. Biosyst Eng 123:19-28

36. IBMER (2007) Catalog of agricultural machines. IBMER (in Polish) 
37. Smith P (2004) Carbon sequestration in croplands: the potential in Europe and the global context. Eur J Agron 20(3):229-236

38. Borzecka-Walker M, Faber A, Borek R (2008) Evaluation of carbon sequestration in energetic crops (Miscanthus and coppice willow). Int Agrophys 22(3):185-190

39. Grogan P, Matthews R (2001) Review of the potential for soil carbon sequestration under bioenergy crops in the U.K. MAFF report on contract NF0418. Institute of Water and Environment, Cranfield University, Silsoe

40. Heller MC, Keoleian GA, Volk TA (2003) Life cycle assessment of a willow bioenergy cropping system. Biomass Bioenergy 25(2): $147-165$

41. Borzecka-Walker M, Faber A, Mizak K, Pudelko R, Syp A (2011) Soil carbon sequestration under bioenergy crops in Poland. In: Ozkaraova Gungor BE (ed) Principles. Application and Assessment in Soil Science. InTech, Rijeka, pp 151-166

42. IPCC (ed) (2007) Climate Change 2007: Synthesis Report. Contribution of Working Groups I, II and III to the Fourth Assessment Report of the Intergovernmental Panel on Climate Change. Intergovernmental Panel on Climate Change, Geneva

43. Crutzen PJ et al (2008) $\mathrm{N}_{2} \mathrm{O}$ release from agro-biofuel production negates global warming reduction by replacing fossil fuels. Atmos Chem Phys 8(2):389-395

44. ECETOC (1994) Ammonia emission to air in Western Europe. European Centre for Eotoxicology and Toxicology Chemicals, Brussels

45. Iriarte A, Rieradevall J, Gabarrell X (2010) Life cycle assessment of sunflower and rapeseed as energy crops under Chilean conditions. J Clean Prod 18(4):336-345

46. Börjesson P (2006) Life cycle assessment of willow production. Institutionen för teknik och samhälle. Lunds Tekniska Högskola, Lund

47. Borzecka-Walker M, Faber A, Pudelko R, Kozyra J, Syp A, Borek R (2011) Life cycle assessment (LCA) of crops for energy production. J Food Agric Environ 9(3-4):698-700

48. Goedkoop M, Oele M, de Schryver A, Vieira M, Hegger S (2010) SimaPro database manual: methods library. PRé Consultants, Amersfoort

49. Gasol CM, Gabarrell X, Anton A, Rigola M, Carrasco J, Ciria P, Rieradevall J (2009) LCA of poplar bioenergy system compared with Brassica carinata energy crop and natural gas in regional scenario. Biomass Bioenergy 33(1):119-129

50. González-García S, Iribarren D, Susmozas A, Dufour J, Murphy RJ (2012) Life cycle assessment of two alternative bioenergy systems involving Salix spp. biomass: Bioethanol production and power generation. Appl Energy 95:111-122

51. Borzecka-Walker M, Faber A, Pudelko R, Kozyra J, Syp A, Borek R (2011) Life cycle assessment (LCA) of crops for energy production. J Food Agric Environ 9(3-4):698-700

52. Monti A, Fazio S, Venturi G (2009) Cradle-to-farm gate life cycle assessment in perennial energy crops. Eur J Agron 31(2):77-84

53. Krzyzaniak M, Stolarski M, Śnieg M, Christou M, Alexopoulou E (2013) Life cycle assessment of Crambe abyssinica production for an integrated multi-product biorefinery. Environ Biotechnol 9(2): $72-80$

54. OECD (2008) Environmental performance of agriculture at a glance. OECD, Paris

55. HELCOM (2009) Eutrophication in the Baltic Sea - an integrated thematic assessment of the effects of nutrient enrichment and eutrophication in the Baltic Sea region. Baltic Sea Environment Proceedings No. 115B. Helsinki Commission, Helsinki

56. Sobolewska A (2006) The influence of the Polish agrienvironmental programme on the losses of nitrogen from crop production. Zesz Nauk Akad Roln Wrocław 540:455-460 (in Polish with English summary)

57. Djomo SN, Kasmioui OE, Ceulemans R (2011) Energy and greenhouse gas balance of bioenergy production from poplar and willow: a review. GCB Bioenergy 3(3):181-197

58. Eggleston HS, Buendia L, Miwa K, Ngara T, Tanabe K (2006) IPCC Guidelines for National Greenhouse Gas Inventories, Institute for Global Environmental Strategies (IGES), Hayama

59. Vande Walle I, Van Camp N, Van de Casteele L, Verheyen K, Lemeur R (2007) Short-rotation forestry of birch, maple, poplar and willow in Flanders (Belgium) II. Energy production and $\mathrm{CO} 2$ emission reduction potential. Biomass Bioenergy 31(5):276-283

60. Schwaiger H, Schlamadinger B (1998) The potential of fuelwood to reduce greenhouse gas emissions in Europe. Biomass Bioenergy 15(4-5):369-377

61. Kimming M, Sundberg C, Nordberg Å, Baky A, Bernesson S, Norén O, Hansson PA (2011) Biomass from agriculture in smallscale combined heat and power plants - a comparative life cycle assessment. Biomass Bioenergy 35(4):1572-1581

62. Styles D, Jones MB (2007) Energy crops in Ireland: quantifying the potential life-cycle greenhouse gas reductions of energy-crop electricity. Biomass Bioenergy 31(11-12):759-772

63. Black MJ, Whittaker C, Hosseini SA, Diaz-Chavez R, Woods J, Murphy RJ (2011) Life cycle assessment and sustainability methodologies for assessing industrial crops, processes and end products. Ind Crop Prod 34(2):1332-1339 